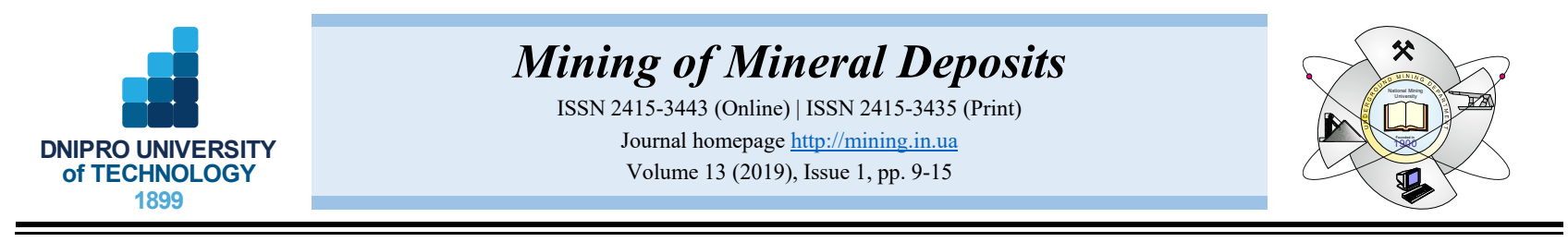

UDC 622.023 .43

https://doi.org/10.33271/mining13.01.009

\title{
EVALUATION OF SOME CERAMIC PROPERTIES OF GADABIU CLAY DEPOSIT (KWALI AREA COUNCIL, ABUJA, NIGERIA)
}

\author{
R.A. Osemenam ${ }^{1}$, T.B. Afeni ${ }^{1}$, V.A. Alfred ${ }^{2 *}$, J.N. Onwualu-John ${ }^{3}$ \\ ${ }^{I}$ Federal University of Technology Akure, Akure, Nigeria \\ ${ }^{2}$ West African Ceramics Ltd, Ajaokuta, Nigeria \\ ${ }^{3}$ University of Port Harcourt, Port Harcourt, Nigeria \\ *Corresponding author: e-mail alfredvictorayodele@gmail.com, tel. +2347032571479
}

\begin{abstract}
Purpose. To evaluate some ceramic properties of Gadabiu clay deposit, Kwali Area Council, Abuja Nigeria.

Methods. Soil samples from the study area were subjected to various physical and mechanical tests such as; X-ray diffraction (XRD), porosity, grain size distribution, cold crush strength, modulus of rupture, linear shrinkage, bulk density, water absorption, loss on ignition, moisture content, plasticity index and refractoriness.

Findings. Results of XRD of the samples indicate that the deposit is of three crystalline components of quartz $64.73 \%$, feldspar $-6.05 \%$ and kaolinite $-29.22 \%$. XRD also identified the dominant oxide compositions of the clay to be silicon oxide and aluminum oxide; while titanium oxide and manganese oxide were found in traces. Laboratory analysis on physical properties of the clay like porosity, grain size distribution, cold crushing strength, modulus of rupture, linear shrinkage, bulk density, water absorption, loss on ignition, moisture content, plasticity index and refractoriness were carried out, and well presented in the paper.
\end{abstract}

Originality. The results can be compared to standard requirements in clay soil for ceramic productions.

Practical implications. The results from this investigation can guide intending investors in their decision making. It can also be used as supporting document when applying for mine license and bank loan.

Keywords: clay, ceramics, physical and mechanical properties, ceramics, X-ray diffraction, plasticity index

\section{INTRODUCTION}

Clay is a sedimentary mineral that is widely distributed across the world. It has been an important mineral for mankind from ancient time. It was used by early men for the constructions of simple shelter and in the production of some domestic utensils like plates, pots and buckets. Clay has gained an increase usage as raw materials in ceramics industries all over the world. It is found in almost all the states in Nigeria with estimated proven reserves in billions of tons (Adediran, Adeogoke, \& Elezeu, 1989).

Clay is formed either as a product of the chemical weathering of pre-existing granitic rocks and feldspar minerals, particularly in warm tropical and subtropical regions of the world or, as a result of the hydrothermal alteration of granitic rocks. Chemically, clays are hydrous aluminum silicates, ordinarily containing impurities, for example potassium, sodium, calcium, magnesium, or iron, in small amounts (Grim, 1968). Clay has a wide variety of physical characteristic such as plasticity, shrinkage under firing and under air-drying, fineness of grain after firing, hardness, cohesion, and ability of the surface to take decoration.

Clay deposits are widely distributed on the basement complex of Nigeria (Ajayi \& Agagu, 1981; Emofurieta \& Salami, 1988). The southern part of the Federal Capital Territory (FCT) falls in the Patti formation of the Southern Bida Basin (Fig. 1) which is noted for carbonaceous shale and clay stones that are interbedded with sandstones and siltstones (Obaje, 2009).

Evaluations of some clay deposits in Nigeria has shown that Nigerian clays are good for ceramics making because of their thermal shock resistance, crushing strength, bulk density and low iron content (Omowumi, 2001; Abolarin, Olugboji, \& Ugwokwe, 2004).

Most of the clays in Southern Bida Basin, especially in the Patti formation from Ahoko village in Kogi state through Abaji and kwali Area Councils of FCT are very good for ceramics production when mixed with other clay types. Clays in these areas have been used by West African Ceramics Ltd for ceramics production for more than fifteen years.

(C) 2018. R.A. Osemenam, T.B. Afeni, V.A. Alfred, J.N. Onwualu-John. Published by the Dnipro University of Technology on behalf of Mining of Mineral Deposits This is an Open Access article distributed under the terms of the Creative Commons Attribution License (http://creativecommons.org/licenses/by/4.0/), which permits unrestricted reuse, distribution, and reproduction in any medium, provided the original work is properly cited. 


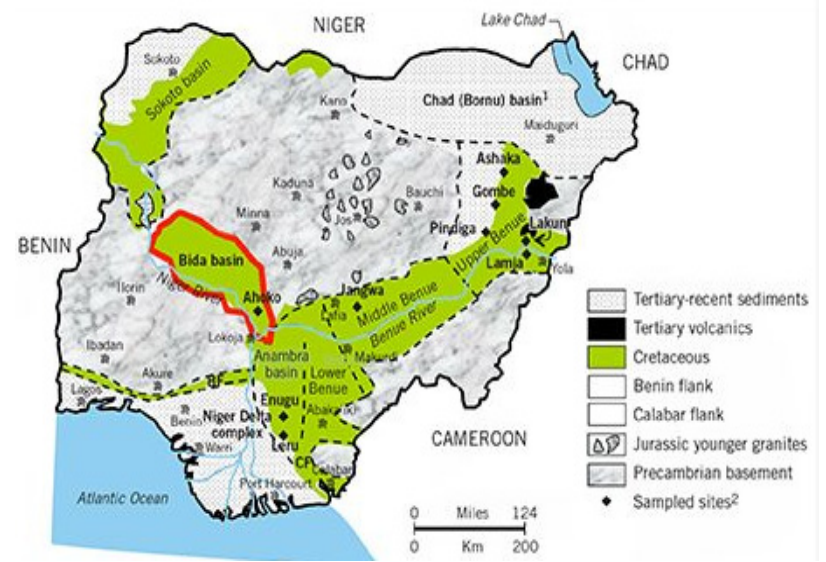

Figure 1. Geological map of Nigeria showing the study areaBida Basin (Obaje, 2009)

Ceramics products like floor and wall tiles, toilet and kitchen wares, POP ceilings and roofing are in constant demands in Nigeria as a result of increase in construction of housing, road, bridges, and other civil structures across the country. This has made exploration and exploitation of good plastic clay important for entrepreneurs who wish to invest in the manufacturing of these products. Gadabiu is in Kwali Area Council in the Federal Capital Territory, along Abuja-Lokoja Highway.

\section{EXPERIMENTAL PROCEDURE}

\subsection{Description of the study area}

$500 \times 500 \mathrm{~m}$ (25 hectares) area of land was delineated for the purpose of this research. The landmass was divided into four equal squares of $250 \times 250 \mathrm{~m}$. Samples were taken from the centres of the $250 \times 250 \mathrm{~m}$ squares in order to get a fair representation. Samples collected at $3 \mathrm{~m}$ depth where the clay bed first occurs were tagged $\mathrm{S}_{11}, \mathrm{~S}_{21}, \mathrm{~S}_{31}, \mathrm{~S}_{41}$. The first digits, 1, 2, 3 and 4 of the subscripts represent the sample numbers collected from the centre of the smaller squares while the second digit in the subscript, i.e. 1, represents the first bed of clay formation. Samples collected at an average depth of $7 \mathrm{~m}$, where the second clay bed is formed were tagged $\mathrm{S}_{12}$, $\mathrm{S}_{22}, \mathrm{~S}_{32}$, and $\mathrm{S}_{42}$ while those collected at an average depth of $10 \mathrm{~m}$ are labeled $\mathrm{S}_{13}, \mathrm{~S}_{23}, \mathrm{~S}_{33}, \mathrm{~S}_{43}$. In all, twelve samples were collected and analyzed in the laboratory.

Gadabiu has an annual rainfall of between 1100 and $1600 \mathrm{~mm}$ from April to October. The samples for this research were obtained in June. The amount of precipitation during this month may slightly affect the laboratory results, especially moisture related properties because of the hydrophilic nature of Gadabiu clay.

\subsection{Laboratory determination of grain size of clay distribution}

Test Procedures: $50 \mathrm{~g}$ of the sample was poured into the Mason jar and about $75 \mathrm{cl}$ of water added.

$20 \mathrm{cl}$ of non-foaming detergent was added and the mixture was stirred with a spatula. The addiction of the detergent was to ease the breaking of the clay samples into it component mineral particles.

The arrangements were allowed to stay for 48 hours to give time for the aggregate to separate and settle.
After 48 hours, gravity had separated the mixture into four distinct layers of gravel at the uppermost, followed by sand, silt and clay in that order. With a meter rule, the measurements of the thickness of each layer were taken and recorded.

The percentage of each component was calculated. Twelve set of Mason jars were used for all the twelve samples collected.

\subsection{Laboratory determination of plasticity index of clay using Atterberg-Casagrande test}

\subsubsection{Plastic limit determination}

Test Procedures: $30 \mathrm{~g}$ of air-dried soil from thoroughly mixed samples which had passed through $425 \mu \mathrm{m}$ sieve were mixed with distilled water in evaporating dishes and were left for 24 hour for "naturing".

$8 \mathrm{~g}$ of the clay paste was rolled with the fingers gently on a glass plate. The rate of rolling was approximately 85 strokes per minute to form a $3 \mathrm{~mm}$ diameter ball.

The diameter of the rolled clay was intermittently measured with a calipers. When the clay mass finally crumbled at $3 \mathrm{~mm}$, the water content of the crumbled sample was then determine.

The experiment was repeated on the same specimen for three times to avoid error. The average of the results was used to evaluate the plastic limit.

\subsubsection{Liquid limit determination using Atterberg-Casagrande test}

Test Procedures: $20 \mathrm{~g}$ of the clay sample was mixed with $30 \mathrm{ml}$ of water in a porcelain bowl of $10 \mathrm{~cm}$ diameter.

A groove was cut with a spatula of $13.5 \mathrm{~mm}$ through the clay paste at the bottom of the bowl.

The bowl is continually dropped unto a hard robber surface. The height of drop was $10 \mathrm{~cm}$.

The rate of dropping was 120 drops per minutes i.e. 2 drops per second.

The number of drops that caused the groove of $13.5 \mathrm{~mm}$ to close was noted.

The moisture content was noted at that instant.

The graph of moisture contents against the number of drops (blow) was plotted.

The moisture content at 25 drops was noted and recorded as the liquid limit from interpolation of the graph.

The plasticity index $=$ liquid limit - plastic limit.

\subsection{Laboratory determination of loss on ignition of clay sample}

Test and Procedures: the crucible was weighed and the weight recorded as $W_{1}$. About $5 \mathrm{~g}$ of sample was placed into the crucible and heated in the oven to about $110^{\circ} \mathrm{C}$ to drive off moisture. It was allowed to cool for 2 hours, re-weighed and recorded as $W_{2}$. The sample with the crucible was placed back into the furnace and heated for 1 hour to about $900^{\circ} \mathrm{C}$. It was brought out and allowed to cool for 2 hours. It was re-weighed and the weight recorded as $W_{3}$.

Loss of ignition $(\mathrm{LOI})=$ original weight of sample before heating/final weight after heating to $900^{\circ} \mathrm{C}$ :

LOI at $900^{\circ} \mathrm{C}=\frac{\left(W_{3}-\left(W_{2}-W_{1}\right)\right)}{\left(W_{2}-W_{1}\right)} \cdot 100$. 
The sample and the crucible was returned to the furnace and heated for another 1 hour to $1000^{\circ} \mathrm{C}$. It was brought out and allowed to cool for 2 hours. It was weighed and its weight recorded as $W_{4}$ :

LOI at $1000^{\circ} \mathrm{C}=\frac{\left(W_{4}-\left(W_{2}-W_{1}\right)\right)}{\left(W_{2}-W_{1}\right)} \cdot 100$.

The sample and the crucible was returned to the furnace and heated for another 1 hour to $1100^{\circ} \mathrm{C}$. It was brought out and allowed to cool for 2 hours. It was weighed and its weight recorded as $W_{5}$ :

LOI at $1100^{\circ} \mathrm{C}=\frac{\left(W_{5}-\left(W_{2}-W_{1}\right)\right)}{\left(W_{2}-W_{1}\right)} \cdot 100$.

The sample and the crucible was returned to the furnace and heated for another 1 hour to $1200^{\circ} \mathrm{C}$. It was brought out and allowed to cool for 2 hours. It was weighed and its weight recorded as $W_{6}$ :

LOI at $1200^{\circ} \mathrm{C}=\frac{\left(W_{6}-\left(W_{2}-W_{1}\right)\right)}{\left(W_{2}-W_{1}\right)} \cdot 100$.

\subsection{Laboratory determination of clay bulk density}

Test Procedures: the weight of a measuring cylinder was determined and recorded as $W_{1}$. A funnel was suspended above the measuring cylinder. The funnel was filled with dry sample and allow to flow freely into the cylinder. The excess material was scraped off with a straight edge. The capacity of the measuring cylinder, $V$, was the volume of the sample. The sample and the cylinder were then weighed and recorded as $W_{2}$.

Weight of sample $=W_{2}-W_{1}$.

Bulk density = weight of sample/volume of sample:

Bulk density $=\frac{\left(W_{2}-W_{1}\right)}{V}$.

\subsection{Laboratory determination of modulus of rupture (MOR) of clay}

Test Procedures: the dry samples were moistened and mixed to a workable state. The weighed sample was cast in wooden molds coated with thin film of machine oil. The bars were air-dry for 48 hours. The bars were kept in a furnace operated at different temperature of 900, 1000, 1100 and $1200^{\circ} \mathrm{C}$ and fired for approximately 10 hours. The bars were removed and cool.

Each bar was fixed to demson strength testing machine and the loads that caused failure were calculated:

$\mathrm{MOR}=\frac{3 P L}{2 b h^{2}}$,

where:

$P$ - breaking load in $\mathrm{Kg}$;

$L$ - distance between supports;

$B$ - breadth of sample;

$h$ - height of sample.

\subsection{Laboratory determination of the chemical composition and crystalline components of clay X-ray diffraction (XRD)}

Equipment and materials: X-ray diffractometer, instrument for grinding, and a sample holder.

Test Procedures: the smear method was used to prepare the sample for XRD analysis because it is a quick method for bulk sample constituent.

About $5 \mathrm{~g}$ of each sample was obtained and crushed thoroughly with mortar and pestle. Powdered sample were passed through a 200 mesh sieve. The very fine powder was mixed with ethanol solution and spread evenly over a slide. The slide was placed under the XRD machine and after 2 minutes of processing; the results of the mineral composition and mineral contents were displayed on the connected monitor.

\section{RESULTS AND DISCUSSION}

\subsection{Grain size distribution}

Table 1 shows that the clay contents of the sample increase with depth. The suitability of clay material for ceramics production in multilayer clay deposit increases with depth because clay of higher plasticity tends to occur at greater depth. Although, this translates to higher mining cost for deeper deposit as a result of cost of overburden removal, however, this extra mining cost can be offset by the low cost of processing clay of higher grade. Clay of higher grade requires less processing cost.

Table 1. Overall average particle size distribution at 3, 7 and $10 \mathrm{~m}$ depth (Alfred, 2017)

\begin{tabular}{ccccc}
\hline $\begin{array}{c}\text { Layer } \\
\text { of clay }\end{array}$ & Gravel (\%) & Sand (\%) & Silt (\%) & Clay (\%) \\
\hline 1 & 4.6 & 13.8 & 19.5 & 62.1 \\
2 & 2.9 & 14.4 & 18.1 & 64.6 \\
3 & 1.4 & 10.4 & 20.0 & 68.3 \\
Average & 3.0 & 12.9 & 19.2 & 65.0 \\
\hline
\end{tabular}

Figure 2 shows the grain size distribution with clay having a total percentage of $65 \%$. These values are relatively high and good for their plasticity and mouldability (Allen, 1986).

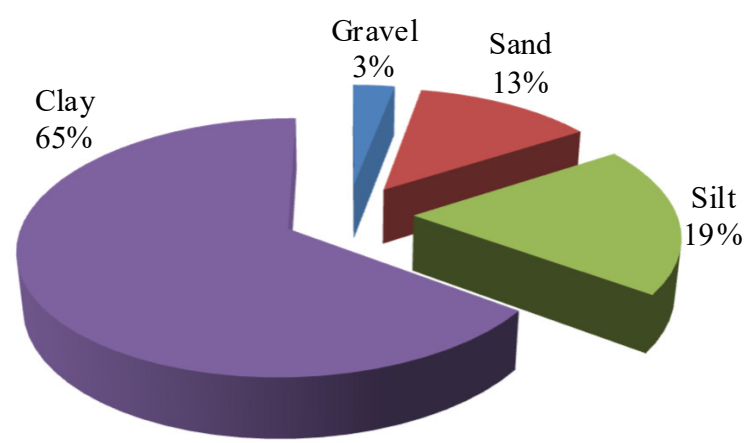

Figure 2. Grain size distribution

\subsection{Plasticity index}

Table 2 shows the average plasticity index for deferent depths. The plasticity index at bed 1 depth has a range of $1.4 \%$ and an average of $31.1 \%$. 
Table 2. Total average plasticity index

\begin{tabular}{ccccc}
\hline Layer & Bed 1 & Bed 2 & Bed 3 & Overall average \\
\hline $\begin{array}{c}\text { Individual } \\
\text { average, \% }\end{array}$ & 31.08 & 43.04 & 49.78 & 41.30 \\
\hline
\end{tabular}

The plasticity index at bed 2 has a range of $0.4 \%$ and the average is $43.0 \%$. The plasticity of the material at bed 3 has a range of $2.0 \%$ while its average plasticity index is $49.8 \%$ (as shown in Figure 3).

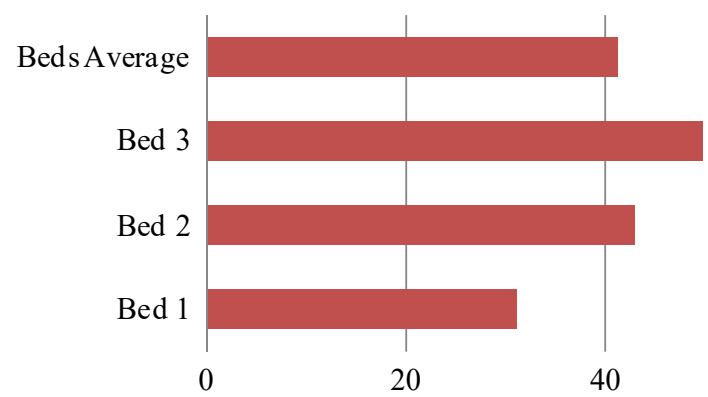

Plasticity index for each bed, \%

\section{Figure 3. Plasticity indices comparison on each bed}

The plasticity index of the deposit increases with depth. High plastic clay is more suitable for ceramics production due to its ease of moulding. Therefore, the clay deposit occurring at bed 3 is more suitable for clay manufacturing. Overall plasticity index is $40.27 \%$ which for the clays studied indicates that they are suitable for the production of ceramic clays, as Grimshaw (1971) prescribed a range of $10-60 \%$ for clay used in ceramic production.

\subsection{Some of the engineering properties of the clay}

The usability of clay for ceramics production is greatly determined by its plasticity. Plasticity of clay is determined by its moisture content which increases with depth in multilayer clay deposit. From the results presented in Table 3, the plasticity of the clay samples at $3 \mathrm{~m}$ depth $\left(\mathrm{S}_{11}-\mathrm{S}_{41}\right)$ varies between 26.3 and $26.5 \%$. Plasticity of clay samples from $7 \mathrm{~m}$ depth $\left(\mathrm{S}_{12}-\mathrm{S}_{42}\right)$ ranges between 17.3 to $17.7 \%$. Plasticity of clay collected at $10 \mathrm{~m}$ depth $\left(\mathrm{S}_{13}-\mathrm{S}_{43}\right)$ is between 21.8 and $22.3 \%$.

Table 3. Average moisture content, $\mathrm{pH}$ value and loss on ignition (Alfred, 2017)

\begin{tabular}{cccc}
\hline Bed & $\begin{array}{c}\text { Average } \% \\
\text { moisture content }\end{array}$ & pH value & $\begin{array}{c}\text { \% loss on } \\
\text { ignition }\end{array}$ \\
\hline 1 & 26.4 & 6.23 & 3.76 \\
2 & 17.5 & 6.45 & 3.24 \\
3 & 22.2 & 6.73 & 2.24 \\
Overall & 22.0 & 6.47 & 3.08 \\
average & & & \\
\hline
\end{tabular}

The plasticity increases with depth due to increase in water content. However, the plasticity of samples collected at $3 \mathrm{~m}$ depth close to the surface is higher than those collected at $7 \mathrm{~m}$ depth because the samples were collected in June when rainfall was at its maximum. Due to the water retaining ability of clay, the clay close to the surface had retained significant amount of water compared to the deposit at the second bed. Water tends to percolate down the soil; the reason moisture content tends to increase with depth. With these results, clay from $10 \mathrm{~m}$ depth is more suitable for ceramics product than those from 3 and $7 \mathrm{~m}$ depth. Overall water content as shown in Table 3 is $22 \%$. This conforms to $22 \%$ suggested by Banaszak (2013) for good ceramic production. The moisture content of each bed is shown in Figure 4.

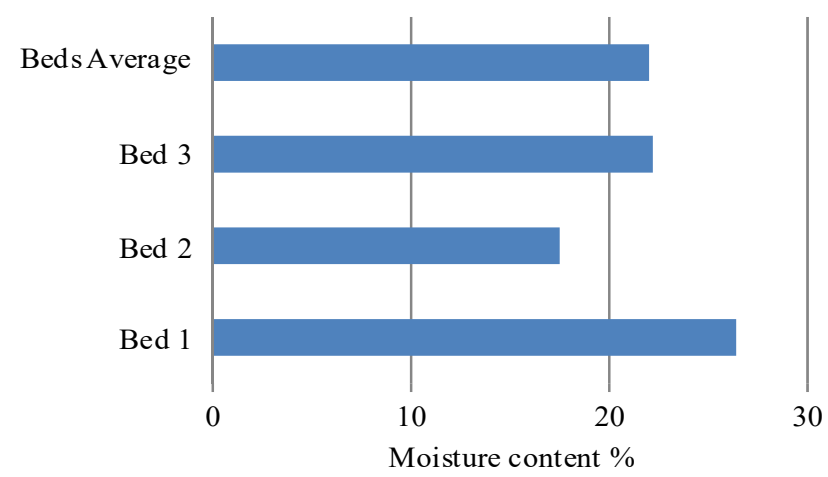

Figure 4. Moisture content

The $\mathrm{pH}$ values of the samples are slightly higher for the samples collected at $10 \mathrm{~m}$ depth than samples collected at 7 and at $3 \mathrm{~m}$ depth. Acidity affects the choice of clay materials as raw materials in ceramics manufacturing. Clay with lower acidity is usually favoured. Clay of higher acidity may easily corrode plant metallic equipment.

Loss on ignition (LOI) of the samples also decreases with depth. Samples collected at $3 \mathrm{~m}$ depth have average LOI of $3.76 \%$, samples collected at $7 \mathrm{~m}$ depth have average LOI of $3.24 \%$ while the samples at $10 \mathrm{~m}$ depth has average LOI of $2.24 \%$.

\subsection{Modulus of rupture (MOR)}

From the results presented in Table 4, the modulus of rupture of the samples at different temperature from $900^{\circ} \mathrm{C}$ through 1000,1100 to $1200^{\circ} \mathrm{C}$ show an increase in the strength of the specimens as the temperature increases.

Table 4. Total average modulus of rupture (MOR) for the deposit at varying temperature (Alfred, 2017)

\begin{tabular}{ccccc}
\hline \multirow{2}{*}{ Bed } & \multicolumn{4}{c}{ Average MOR, N/m ${ }^{2}$} \\
\cline { 2 - 5 } & $900^{\circ} \mathrm{C}$ & $1000^{\circ} \mathrm{C}$ & $1100^{\circ} \mathrm{C}$ & $1200^{\circ} \mathrm{C}$ \\
\hline 1 & 30.55 & 34.4 & 40.90 & 61.57 \\
2 & 41.79 & 45.88 & 51.38 & 71.47 \\
3 & 57.64 & 70.69 & 78.63 & 88.30 \\
Average & 43.33 & 50.33 & 56.97 & 73.78 \\
\hline
\end{tabular}

Also, the modulus of rupture increases with depth. The clay bed at $10 \mathrm{~m}$ depth has greater strength than the beds at 3 and $7 \mathrm{~m}$ depth respectively. These strength results are within the acceptable range for clay suitability for ceramics. Overall average of MOR for the deposit is $43.33,50.30,57.00,55.40$ for $900,1000,1100$ and $1200^{\circ} \mathrm{C}$ respectively (as shown Figure 5).

\subsection{Fired linear shrinkage}

Table 5 shows increase in linear shrinkage as temperature increases. Clay at greater depth has lesser shrinkage values. As reported by (Chester, 1983), the allowable linear shrinkage range for quality ceramics is within $7-10 \%$. Clay deposits at $7 \mathrm{~m}$ depth and at $10 \mathrm{~m}$ depth are more suitable for ceramics production. 


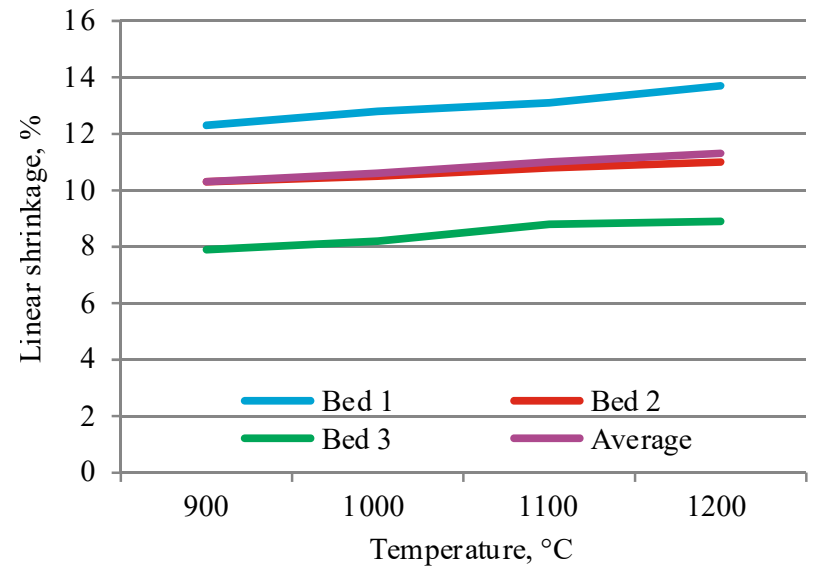

Figure 5. Modulus of rupture (MOR)

Table 5. Total average linear shrinkage for the deposit at varying temperature (Alfred, 2017)

\begin{tabular}{ccccc}
\hline \multirow{2}{*}{ Bed } & \multicolumn{4}{c}{ Average linear shrinkage, \% } \\
\cline { 2 - 5 } & $900^{\circ} \mathrm{C}$ & $1000^{\circ} \mathrm{C}$ & $1100^{\circ} \mathrm{C}$ & $1200^{\circ} \mathrm{C}$ \\
\hline 1 & 12.3 & 12.8 & 13.1 & 13.7 \\
2 & 10.3 & 10.5 & 10.8 & 11.0 \\
3 & 7.9 & 8.2 & 8.8 & 8.9 \\
Average & 10.2 & 10.5 & 10.9 & 11.2 \\
\hline
\end{tabular}

Figure 6 shows the graph of fired linear shrinkage with temperature.

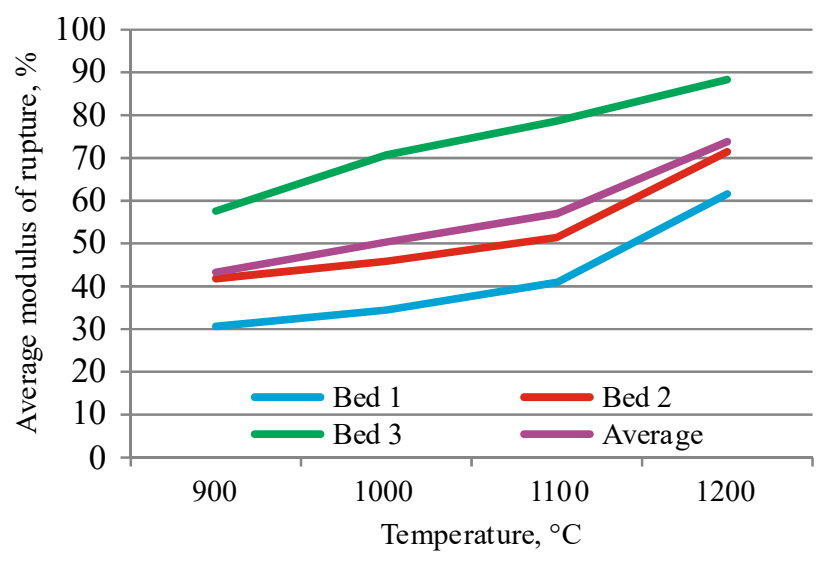

Figure 6. Linear shrinkage against temperature

\subsection{Bulk density}

Table 6 shows the bulk densities of the various clay samples at varying Temperature from 900 to $1200^{\circ} \mathrm{C}$. Bulk density increases as furnace temperature increases. The bulk density of clay deposit at greater depth is slightly higher than those of shallower debt.

Table 6. Total average bulk density for the deposit at varying temperature (Alfred, 2017)

\begin{tabular}{ccccc}
\hline \multirow{2}{*}{ Bed } & \multicolumn{4}{c}{ Average bulk density, $\mathrm{g} / \mathrm{cm}^{3}$} \\
\cline { 2 - 5 } & $900^{\circ} \mathrm{C}$ & $1000^{\circ} \mathrm{C}$ & $1100^{\circ} \mathrm{C}$ & $1200^{\circ} \mathrm{C}$ \\
\hline 1 & 1.45 & 1.52 & 2.13 & 2.63 \\
2 & 1.64 & 1.77 & 2.49 & 2.90 \\
3 & 1.74 & 1.88 & 2.77 & 3.14 \\
Average & 1.61 & 1.72 & 2.46 & 2.89 \\
\hline
\end{tabular}

The best range of densities for ceramic clay at $1200^{\circ} \mathrm{C}$ is between $2.2-2.8 \mathrm{~g} / \mathrm{cm}^{2}$ (Omowumi, 2001).
Almost all the clay samples fall within this range. Figure 7 shows the bulk density of each bed.

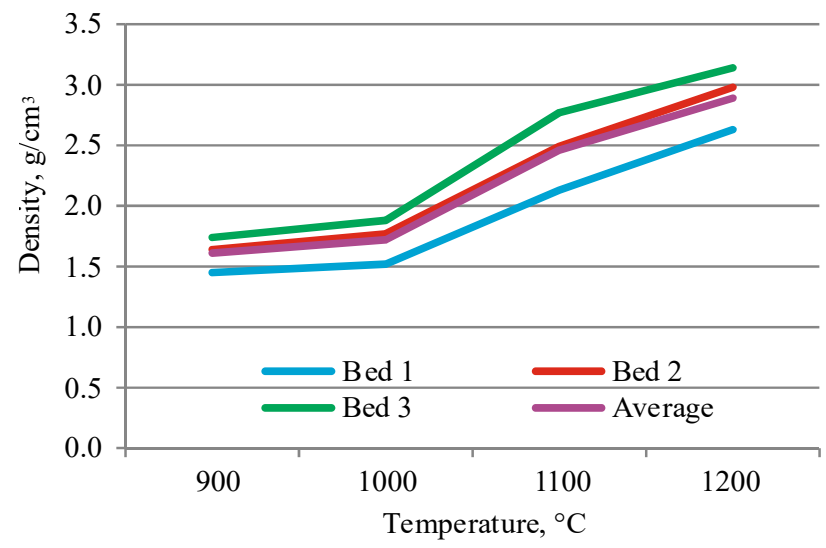

Figure 7. Bulk density against temperature

\subsection{Water absorption}

The percentage water absorption capacity of the clay samples fired between 900 to $1200^{\circ} \mathrm{C}$ is recorded in Table 7 while its graphical representation is presented in Figure 8.

Table 7. Average water absorption for the clay beds (Alfred, 2017)

\begin{tabular}{ccccc}
\hline \multirow{2}{*}{ Bed } & \multicolumn{4}{c}{ Average water absorption, \% } \\
\cline { 2 - 5 } & $900^{\circ} \mathrm{C}$ & $1000^{\circ} \mathrm{C}$ & $1100^{\circ} \mathrm{C}$ & $1200^{\circ} \mathrm{C}$ \\
\hline 1 & 20.36 & 18.03 & 13.88 & 13.10 \\
2 & 18.33 & 14.56 & 12.55 & 11.34 \\
3 & 13.71 & 13.20 & 11.04 & 10.38 \\
Average & 17.47 & 15.26 & 12.49 & 11.61 \\
\hline
\end{tabular}

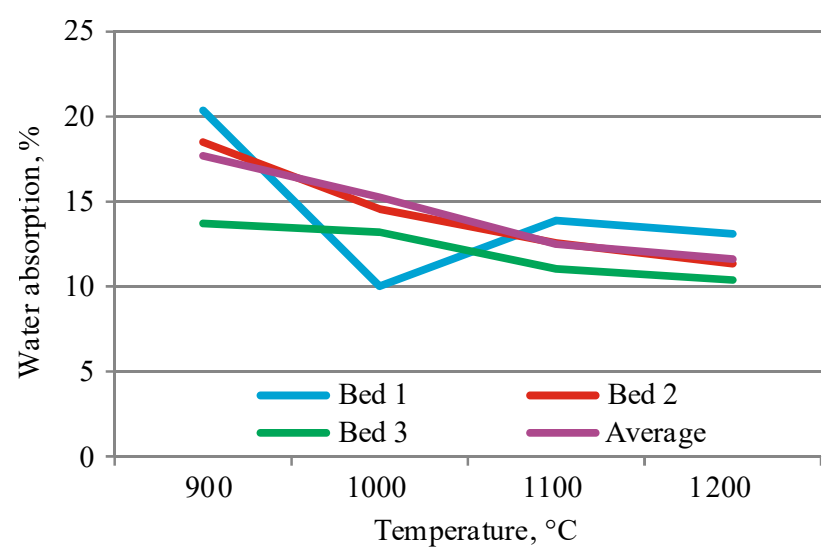

Figure 8. Water absorption at different temperature

The clay deposit at $3 \mathrm{~m}$ depth has the highest water absorption capacity ranging from 20.64 to $12.99 \%$. Water absorption capacities at $7 \mathrm{~m}$ depth range from 18.74 to $11.01 \%$ while water absorption capacity at $10 \mathrm{~m}$ depth is between 14.02 to $10.33 \%$. Water absorption capacity decreases with temperature of firing and also decreases with depth.

\subsection{Cold crushing strength}

Column four in Table 8 shows the average values of the samples' cold crushing strength. The value increases with depth. Chester (1983) reported that the recommended range of cold crushing strength for ceramics clay is between $352-564 \mathrm{~kg} / \mathrm{cm}^{2}$. 
Table 8. Overall average cold crushing strength (Alfred, 2017)

\begin{tabular}{cccc}
\hline \multirow{2}{*}{ Sample } & \multicolumn{3}{c}{ Cold crushing strength, $\mathrm{kg} / \mathrm{cm}^{2}$} \\
\cline { 2 - 4 } & Bed 1 & Bed 2 & Bed 3 \\
\hline $\mathrm{S}_{1}$ & 254 & 365 & 440 \\
$\mathrm{~S}_{2}$ & 250 & 358 & 461 \\
$\mathrm{~S}_{3}$ & 258 & 357 & 468 \\
$\mathrm{~S}_{4}$ & 251 & 347 & 439 \\
Average & 253 & 357 & 452 \\
\hline
\end{tabular}

All the values fall between these ranges. This means that the three beds of the clay deposit have good strength at room temperature.

\subsection{Chemical composition of the samples}

Table 9 shows the average chemical composition of the samples collected at different beds; the results show that in all the different cases of layers sampled, silicone oxide and aluminum oxide are the major constituents while titanium oxide, manganese oxide, phosphorous oxide and calcium oxide occur in traces. Comparing the chemical composition of the beds, it is observed that the iron content decreases as the depth increases while the aluminum oxide content increases with as the depth goes deeper.

Table 9. Average chemical composition of the samples at different depths (Alfred, 2017)

\begin{tabular}{ccccc}
\hline Compo- & \multicolumn{4}{c}{ Average chemical composition, \% } \\
\cline { 2 - 5 } nents & Bed 1 & Bed 2 & Bed 3 & Average \\
\hline $\mathrm{SiO}_{2}$ & 50.66 & 50.61 & 50.86 & 50.71 \\
$\mathrm{Al}_{2} \mathrm{O}_{3}$ & 39.54 & 41.85 & 43.64 & 41.68 \\
$\mathrm{TiO}_{2}$ & 0.01 & 0.02 & 0.02 & 0.02 \\
$\mathrm{Fe}_{2} \mathrm{O}_{3}$ & 3.74 & 1.72 & 1.03 & 2.16 \\
$\mathrm{MgO}$ & 0.06 & 0.01 & 0.04 & 0.04 \\
$\mathrm{MnO}$ & 0.00 & 0.01 & 0.02 & 0.01 \\
$\mathrm{CaO}$ & 0.02 & 0.03 & 0.04 & 0.03 \\
$\mathrm{Na} 2$ & 1.87 & 2.11 & 1.52 & 1.83 \\
$\mathrm{~K}_{2} \mathrm{O}$ & 0.68 & 0.57 & 0.50 & 0.58 \\
$\mathrm{P}_{2} \mathrm{O}_{5}$ & 0.02 & 0.03 & 0.02 & 0.02 \\
$\mathrm{LOI}$ & 3.76 & 3.24 & 2.26 & 3.09 \\
Total & 100.36 & 100.2 & 99.63 & 100.17 \\
\hline
\end{tabular}

\subsection{Mineral contents of the clay samples}

Tables 10 show the mineralogical composition of the deposit. Average quartz content is $64.73 \%$, feldspar $6.05 \%$ and kaolinite $29.22 \%$. Figure 9 shows the percentage distributions of the mineral.

Table 10. Comparison of the mineral content from each bed

\begin{tabular}{cccc}
\hline Bed & $\begin{array}{c}\text { Average } \\
\text { quartz, \% }\end{array}$ & $\begin{array}{c}\text { Average } \\
\text { feldspar, \% }\end{array}$ & $\begin{array}{c}\text { Average } \\
\text { kaolinite, \% }\end{array}$ \\
\hline 1 & 61.60 & 7.18 & 31.22 \\
2 & 64.33 & 6.17 & 29.50 \\
3 & 68.25 & 4.81 & 26.94 \\
$\begin{array}{c}\text { Overall } \\
\text { average }\end{array}$ & 64.73 & 6.05 & 29.22 \\
\hline
\end{tabular}

\section{CONCLUSIONS}

This study investigated some ceramic properties of clay in the study area for industrial suitability. The laboratory analysis results show that the grain size distribution for the deposit increases as the depth increases with the clay material having the highest proportion of the distribution.

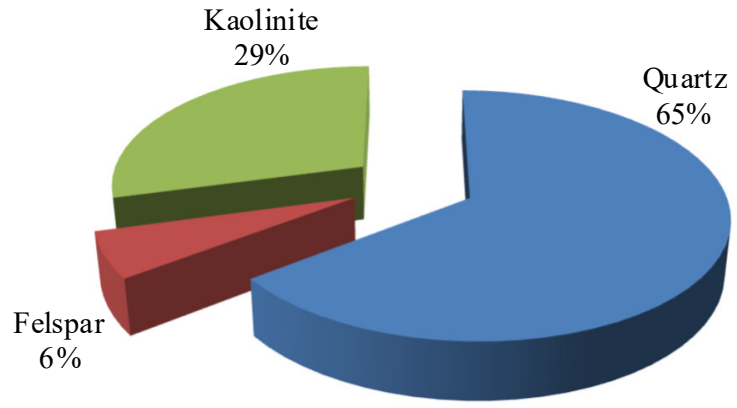

Figure 9. Average Mineral Composition

The average plastic index falls above the minimum requirement suggested for producing suitable ceramics. The results for the average cold crushing strength, water absorption, modulus of rupture, bulk densities and fired linear shrinkage are within acceptable standards for suitable ceramics. X-ray diffraction for the mineralogical compositions of the samples shows the overall average value of the deposit as: quartz $-64.73 \%$, felspar $-6.05 \%$ and kaolinite $-29.22 \%$. The results from the X-ray diffraction analysis for the chemical composition determination were found to fall within the standard range recommended for a suitable ceramic.

\section{ACKNOWLEDGEMENTS}

The authors are grateful for the support of management of West African Ceramics Ltd, Ajaokuta, Kogi State, Nigeria.

\section{REFERENCES}

Abolarin, M.S., Olugboji, O.M., \& Ugwokwe, C. (2004). Experimental investigation on local refractory materials for furnace construction. In Proceedings of the $5^{\text {th }}$ Annual Engineering Conference (pp. 82-85). Minna, Nigeria: Federal University of Technology Minna.

Adediran, S.A., Adeogoke, O.S., \& Elezeu, A.A. (1989). Guide to the non-metallic mineral industrial potentials of Nigeria. Abuja, Nigeria: Raw Material Research and Development Council.

Ajayi, J.O., \& Agagu, O.K. (1981). Mineralogy of primary clay deposit in the basement complex areas of Nigeria. Journal of Mining Geology, 1(18), 27-30.

Alfred, V.A. (2017). Reserve evaluation and estimation for clay deposit at Gadabiu, Kwali Area Council, Abuja, Nigeria. PhD Thesis. Akure, Nigeria: Federal University of Technology Akure.

Allen, D. (1986). Pottery science: materials, process and products. Hemel Hempstead, United Kingdom: Ellis Horwood Ltd.

Banaszak, J. (2013). The moisture content and mechanical properties of ceramic masses. Ceramic Materials, 65(1), 40-43.

Chester, J.H. (1983). Refractoriness, production and properties. London, United Kingdom: The Iron and Steel Institute.

Emofurieta, W.O., \& Salami, A.O. (1988). A comparative study of the two kaolin deposits in South Western Nigeria. Journal of Mining Geology, 24(1), 15-20.

Grim, R.E. (1968). Clay mineralogy. New York, United States: Mc Graw-Hill.

Grimshaw, R.W. (1971). The chemistry and physics of clays and allied ceramic materials. London, United Kingdom: Ernest Benn Limited.

Obaje, N.G. (2009). Geology and mineral resources of Nigeria. Berlin, Germany: Lecture Notes in Earth Sciences, Springer. https://doi.org/10.1007/978-3-540-92685-6

Omowumi, O.J. (2001). Characterization of Some Nigerian Clays as Refractory Materials for Furnace Lining. Nigerian Journal of Engineering Metallurgy, 2(3), 1-4. 


\section{ОЦНКА ДЕЯКИХ КЕРАМІЧНИХ ВЛАСТИВОСТЕЙ РОДОВИЩА ГЛИНИ ГАДАБІУ (ТЕРИТОРІАЛЬНА РАДА КВАЛІ, АБУДЖА, НІГЕРІЯ)}

\section{Р.А. Осеменам, Т.Б. Афені, В.А. Альфред, Ж.Н. Онвуалу-Джон}

Мета. Оцінка керамічних властивостей глини родовища Гадабіу, територіальна рада Квалі (Абуджа, Нігерія) на основі фізико-механічних випробувань для можливості їі використання у промислових цілях.

Методика. Були відібрані 12 проб глини родовища з глибин 3, 7 і 10 м та піддані фізичним і механічних випробуванням, а також рентгеноструктурному аналізу (PCA) для визначення пористості, розподілу зерна за величиною, межі міцності на розрив і стиск, лінійного стиску, об'ємної щільності, гігроскопічності, втрати ваги при прокалюванні, вмісту вологи, коефіцієнта пластичності й вогнетривкості.

Результати. Встановлено, що зразки глини родовища містять три кристалічних компоненти: кварц $-64.73 \%$, польовий шпат $-6.05 \%$ і каолініт - 29.22\%. РСА дозволив визначити, що в глинах родовища переважають оксиди кремнію та алюмінію, тоді як оксиди марганцю й титану представлені дуже незначно. Досліджені такі фізичні властивості глини як пористість, розподіл зерна по величині, межа міцності на розрив і стиск, лінійний стиск, об’ємна щільність, гігроскопічність, втрата ваги при прокалюванні, вміст вологи, коефіцієнт пластичності та вогнетривкість, що знаходяться в межах прийнятних стандартів для виробництва кераміки. Встановлено середній пластичний індекс глини, який $є$ вище мінімальних вимог, необхідних для виробництва кераміки.

Наукова новизна. Виявлено зональне покращення фізико-механічних властивостей та сортності глини 3 глибиною (від 3 до 10 м) в умовах родовища Гадабіу.

Практична значимість. Встановлена промислова придатність глини родовища Гадабіу для виробництва кераміки.

Ключові слова: глина, фізично-механічні властивості, кераміка, рентгенівська дифракиія, показник пластичності

\section{ОЦЕНКА НЕКОТОРЫХ КЕРАМИЧЕСКИХ СВОЙСТВ МЕСТОРОЖДЕНИЯ ГЛИНЫ ГАДАБИУ (ТЕРРИТОРИАЛЬНЫЙ СОВЕТ КВАЛИ, АБУДЖА, НИГЕРИЯ)}

\section{Р.А. Осеменам, Т.Б. Афени, В.А. Альфред, Ж.Н. Онвуалу-Джон}

Цель. Оценка керамических свойств глины месторождения Гадабиу, территориальный совет Квали (Абуджа, Нигерия) на основании физико-механических испытаний для возможности ее применения в промышленных целях.

Методика. Были отобраны 12 проб глины месторождения с глубины 3, 7 и 10 м и подвергнуты физическим и механическим испытаниям, а также рентгеноструктурному анализу (РСА) для определения пористости, распределения зерна по величине, предела прочности на разрыв и сжатие, линейного сжатия, объемной плотности, гигроскопичности, потери веса при прокаливании, содержания влаги, коэффициента пластичности и огнеупорности.

Результаты. Установлено, что образцы глины месторождения содержат три кристаллических компонента: кварц $-64.73 \%$, полевой шпат $-6.05 \%$, и каолинит $-29.22 \%$. РСА также позволил определить, что в глинах месторождения преобладают оксиды кремния и алюминия, тогда как оксиды марганца и титана представлены очень незначительно. Исследованы такие физические свойства глины как пористость, распределение зерна по величине, предел прочности на разрыв и сжатие, линейное сжатие, объемная плотность, гигроскопичность, потеря веса при прокаливании, содержание влаги, коэффициент пластичности и огнеупорность, находящиеся в пределах приемлемых стандартов для производства керамики. Установлен средний пластический индекс глины, который является выше минимальных требований, необходимого для производства керамики.

Научная новизна. Выявлено зональное улучшение физико-механических свойств и сортности глины с глубиной (от 3 до 10 м) в условиях месторождения Гадабиу.

Практическая значимость. Установлена промышленная пригодность глины месторождения Гадабиу для производства керамики.

Ключевые слова: глина, физическо-механические свойства, керамика, рентгеновская дифракиия, показатель пластичности

\section{ARTICLE INFO}

Received: 7 January 2018

Accepted: 12 December 2018

Available online: 27 December 2018

\section{ABOUT AUTHORS}

Raymond Azuka Osemenam, Doctor of Philosophy, Senior Lecturer of the Department of Mining Engineering, Federal University of Technology Akure, Ilesha-Akure Expressway, P.M.B. 704, Akure, Ondo State, Nigeria. E-mail: udembaezenia@yahoo.com

Thomas Busuyi Afeni, Doctor of Philosophy, Senior Lecturer of the Department of Mining Engineering, Federal University of Technology Akure, Ilesha-Akure Expressway, P.M.B. 704, Akure, Ondo State, Nigeria. E-mail: tbafeni@futa.edu.ng

Victor Ayodele Alfred, Mine Supervisor of the Department of Mines and Raw Materials, West African Ceramics Ltd, Ogura Village, Near Niger Bridge, 263106, Ajaokuta, Kogi State, Nigeria. E-mail: alfredvictorayodele@gmail.com

Josephine Onwualu-John, Doctor of Philosophy, Senior Lecturer of the Department of Geology, University of Port Harcourt, East-West Road, Choba, 500272, Port Harcourt, Nigeria. E-mail: john_onwualu@yahoo.com 